\title{
Македонската фолклористика во 21 век
}

\author{
Ермис Лафазановски
}

Дебатите кои се водат во рамките на светската фолклористика, поврзани со сопствениот предмет на истражување, методологијата и теоријата, не ја одминуваат ниту македонската фолклористика која во почетните декади на дваесет и првиот век, обидувајќи се да држи чекор со најновите истражувања, се наоѓa во процес на обид за „освежување“ на сопствената наука, наоѓајќи инспирација во сродните хуманистички дисциплини. Во таа насока македонската фолклористика се обидува својата теорија и методологија да ја претстави како збир од претходните богати искуства произлезени од истражувањата во втората половина на дваесеттиот век и новите тенденции.

Клучни зборови: фолклористика, идентитет, методологија, теорија, македонска фолклористика

Намерата ми беше насловот на рефератот Македонската фолклористика во 21 век недвосмислено да упатува на насловот на Алан Дандес и неговата сега веќе класична статија објавена во списанието за американски фолклор во 2005 година со наслов Фолклористиката во дваесет и првиот век (Dundes 2004) затоа што тоа што тој го навел во некои клучни моменти во тој труд можат да се земат како парадигматични не само општо, за моменталната фолклористика како наука во светски рамки туку со исклучоци и поединечно за ситуацијата на фолклористиката како наука во Македонија. Дандес вели:

The state of folkloristics at the beginning of the twenty-first century is depressingly worrisome. Graduate programs in folklore around the world have been disestablished or seriously weakened. Folklore programs in Germany have changed their title in an effort to become ethnology-centered (...). Even in Helsinki, the veritable Mecca of folklore research, the name of the graduate program at the University of Helsinki has been changed. (...) According to the website, "The Department of Folklore Studies, along with the departments of Ethnology, Cultural Anthropology and Archaeology, belongs 
administratively to the Faculty of Arts and the Institute of Cultural Research." ... Here in the United States, the situation is even worse. UCLA's doctoral program in folklore and mythology has been subsumed under the rubric of World Arts and Cultures, and the folklore doctorate has been reduced to one of several options in that expansion of what was formerly a department of dance. (...) Even Indiana University, the acknowledged bastion and beacon of folklore study in the United States, has seen fit to combine folklore with ethnomusicology into one administrative unit (Dundes 2004: 385). ${ }^{1}$

Во овој малку подолг и депресивен цитат, многумина научници кои се занимаваат со фолклористиката во нашата земја па и пошироко на Балканот, можат да препознаат некои елементи на „притисокот“ кои експлицитно или имплицитно го чувствува не само нашата наука туку сродните науки и дисциплини како што се етнологијата и антропологијата. Ние фолклористите одамна сме свесни за несоодветниот и непоткрепениот со „логосот“ на науката, иронизирачки однос на јавноста кон терминот фолклор (Јакимовска 2018), а да не зборуваме за фолклористиката како наука, за која јавноста можеби воопшто не е информирана.

Наспроти овие тенденции, Институтот за фолклор „Марко Цепенков“ веќе седумдесет години се „бори“ со ваквите ветерници, и покрај притисокот кои го чувствува, продолжува да стои на бедемот на институционалната и научна одбрана на фолклорот и фолклористиката. Не еднаш за време на нашите научни дискусии сме дискутирале за причините поради ваквата ситуација и можностите кои ни стојат на располагање за одржување на фолклористиката како една од клучните компоненти на културниот бит на нашето општество бидејќи како што вели Дандес во продолжение - фолклористиката е дисциплина која е понапред од своето време, по тоа што ја препо-

\footnotetext{
1 „Ситуацијата со фолклористиката во дваесет и првиот век е депресивна. Програмите по фолклористика (на светските универзитети е.л.) се или укинати или потполно ослабени. Една од најпрославените катедри по фолклористика во Копенхаген, веќе не постои. Програмите по фолклористика на универзитетите во Германија го промениле насловот и станале етнолошки. Дури и во Хелсинки, меката на фолклористиката името на катедрата за фолклористика е сменето (...) и Одделот за фолклористика, заедно со тој за етнологија и Културана антропологија и археологија, административно им припаѓаат на факултетот за уметност припаѓаaт и Институтот за културолошки истражувања. (...) Тука во Калифорнија, УКЛА, ситуацијата е уште полоша, докторските студии по фолклористика и митологија се сведени на одделот за Светска уметност и култура, и овие програми се подредени во одделот за танц. (...) Дури и најсилната програма по фолклористика во Индијана мораше да го комбинира фолклорот со етномузикологијата во една административна единица."
} 
знава важноста на фолклорот во промовирање на етничката гордост и собирањето на скапоцени информации за откривање на традиционалните когнитивни категории поврзани со погледот на свет и вредностите. Дандес ги открива причините поради состојбата во која се наоѓа светската фолклористика во дваесет и првиот век и вели дека тоа е така поради две причини: недостаток на оригинална теорија и улогата на аматерите кои на нашата дисциплина ѝ донесоа слаба репутација. Што се однесува до првата причина некако можеме да се сложиме со фактот дека недостатокот на оригинална фолклористичка теорија е една од причините поради кои интересот, особено на младите за нашата дисциплина е несоодветен со придобивките кои ова дисциплина ги нуди. Токму затоа фолклористиката во дваесеттиот век се служела со лингвистичката, структуралистичката, и омилената на Дандес психоаналитичка теорија, не успевајќ да оформи еден сопствен поглед на свет и да ги дефинира сопствените вредности. Од друга страна улогата на аматеризмот во рамките на американската фолклористика, можеби е една од тамошните причини, но што се однесува до Балканот или Источна Европа ситуацијата е поинаква со оглед на тоа што фолклорниот аматеризам, да, е многу популарен но не само што според мое мислење има минорно значење туку напротив често, тој помага во дистрибуцијата на традицијата, особено во рамките на мала земја како нашата чиј идентитет исклучиво се базира на фолклорната традиција. Интересно е што и Регина Бендикс во нејзиниот труд За името, професионалниот идентитет, $и$ иднината на дисциплината (Bendix 1998) има слични ставови во врска со иднината на фолклористиката. Токму за овие ставови на Бендикс зборува и Ана Мартиноска (Мартиноска 2018) која прави кратка анализа на состојбата со името на нашата дисциплина поврзана со заклучоците од годишната средба на Американското здружение за фолклористика, на која Бендикс настапила со темата: Што има во името? Размислување за терминот фолклор кој има 150 години и каде што една група фолклористи имплицитно се залага за елиминација на терминот фолклор со оглед на тоа што тој ја маргинализира дисциплината. Се разбира мислењата биле поделени, но прашањето за тоа како терминот да се ослободи од негативното значење што по некогаш го добива, останало.

Тоа што може да се каже за западноевропската фолклористика е дека таа е апсолутно европоцентрична и западноцентрична, како и голем број на науки особено од хуманистичката сфера. Научните истражувања во оваа област главно се концентрирани на фолклористиките на Америка и Западна Европа. За фолклористиката во Источна Европа ниту збор, освен дека (парафразирам) фолклорот често во 
некои земји се употребува и инстурментализира во политички цели а тоа го прават особено тоталитаристичките општества. Јас можеби погрешно тука ја препознав фолклористиката од Источна Европа во втората половина на дваесеттиот век. А ако воопшто се споменува некој тоа е Проп. Но тоа може да е од неколку причини меѓу кои првата е дека едноставно се нема интерес за овие фолклористики на запад, со оглед на тоа дека се национално центрирани или тоа се должи на недостатокот на информации и протокот на идеи. Дандес ги посочува Естонија, Литванија и Латвија како земји кои во дваесет и првиот век ќе ја понесат фолклористиката кон нови хоризонти.

Од сево ова до сега речено разбираме дека македонската фолклористика, како наука не успеала и тоа не по сопствена вина да се афирмира во пошироки европски рамки, со оглед на тоа што знам од сопствено искуство дека оваа наука е кај нас на ранг на балтичките фолклористики. Но за тоа си имаме и ние наши причини. Но секако дека излезот треба да се бара во досега непознатите за светската јавност истражување на фолклористите од Источна Европа.

За состојбата на фолклористиката во нашата држава вклучително и на постоењето на дисциплината во изминатите седумдесет години има анализи, но јас би ги издвоил најновите на Боне Величковски: Институционализацијата и предизвиците со кои се соочува Институтот за фолклор во ерата на глобализацијата (2016) и Меѓу традицијата и модерноста - фолклорот и фолклористиката во Република Македонија (2018), објавени во списанието Македонски фолклор во 2016 и 2018; Илина Јакимовска за Употребата на фолклорот во современата политичка реторика и во популарниот дискурс во Македонија (2018); Ана Ашталковска (Зло)употребата на националното, различните перспективи на „националните“ научни дисциплини во Македонија (2018). Овие се само неколкуте најнови соочувања со „стварноста“ на македонската фолклористика во последните десетина години.

Што се однесува до методолошко теориските аспекти, Величковски во својот труд вели дека:

Во потрага по метода на истражување новата фолклористика се' повеќе се оддалечува од теоријата на книжевност, лингвистиката и митологијата и се приближува кон социологијата. Tоа е точно со оглед на тоа дека поглед врз трудовите кои се објавуваат во Македонија во последните дваесет години ни посведочува за тоа дека постои одредено поместување на теоретското тежиште од структуралистичката теорија кон социологијата, но исчекор во некаква индуктивна метода на истражувањето уште нема. Од друга страна губењето и исчезнувањето на изворната традиција наметнува нови пара- 
дигми на истражување но тоа не значи дека фолклористиката со филолошка и семиотичка ориентација го изгубила предметот на своето истражување (Величковски 2018: 16).

Краток преглед на библиографијата која произлезе во рамките на Институтот во последните дваесет години зборува за тоа дека веќе се напуштија старите теориско методолошки истражувачки принципи во потрага по нови хоризонти.

Моето мислење во врска со предметот и теоријата на фолклористиката е дека ние треба полека да се приближиме кон употребата на фолклористиката во културната анализа на општеството што би значело поимање на фолклористиката како критика на културата при тоа не употребувајќ г го терминот критика во негативна конотација туку како поим кој во својата суштина ја има анализата. Впрочем тоа не значи напуштање на истражувањето на традицијата туку повеќе примена на истражувањето на модалитетите во кои се трансформира традицијата под влијание на, особено во почетокот на дваесет и првиот век, на технолошките иновации, медиумите и пред се електронската и визуелната комуникација. Фолклористиката како медиум за културна анализа, при тоа не изедначувајќи го германскиот термин Volksunde со терминот фолклористика со оглед на тоа што семантичкиот потенцијал на германскиот термин води кон етнологијата, туку пред се' задржувајќ и ја дефиницијата на фолклористиката во богатата македонска традиција, која што пред се́ дава предност на истражувањето на уметничките аспекти на традицијата. Токму затоа и децении наназад една од главните теми на дискусија во Институтот за фолклор била традицијата и современоста, која понекогаш поради преголемиот број на повторувања може да звучи и анахроно и банално а така мислев за тоа додека бев млад и полетен. Денес кога со други очи гледам на минатото знам дека постојаното повторување на терминот традиција и современост не беше ништо друго туку постојан и бескраен обид да се пронајде пат кон новото можеби кон дефиницијата на традицијата како „алатка“ за истражување на современоста. Од тука мислам дека е дојдено времето токму оваа одамна посакувана цел да се спроведе на дело и нашата фолклористичка методологија да биде алатка за културна анализа. Но, за тоа треба нов пристап кон нашиот предмет на истражување од кои можеби ќе произлезе и нова теорија.

Насловот на овој труд исто така крие во себе уште еден парадокс, покрај таа што за потребите на ова излагање заличува со насловот на Дандес. Имено, ние не знаеме освен ако не сме профети што ќе се случи со нашата наука во дваесет и првиот век, какви насоки какви 
теории и какви можности во наредните сто години ќе постигне но можеме да кажеме што се случува во почетокот на дваесет и првиот век. Тоа значи дека коректниот наслов би гласел: Македонската фолклористика во почетокот на дваесет и првиот век, но во тој случај сето тоа што го слушнавме до сега би звучело депресивно, а само „дваесет и првиот век“ сепак дава некаква надеж за светла иднина. А иднината може да биде поинаква ако не се базира само врз мислењето на група интелектуалци ентузијасти туку ако луѓето реално го разбираат фолклорот и фолклористиката во многу пошироки светски рамки како дел од општиот цивилизацискиот мозаик на културни вредност во кои придонесуваме со нашата постојаност. Затоа ќе заклучам со истите зборови со кои го заклучил својот реферат Дандес дали од очај или од среќ: „Ура за фолклорот, ура за фолклористите и ура за Американскиот фолклор.“ А јас ќе речам: Ура за македонскиот фолклор и македонската фолклористика.

\section{Библиографија}

Ашталковска Гајтаноска, Ана (2018). (Зло) употребата на националното различни перспективи за задачите на „националните“ научни дисциплини во Македонија. Македонски фолклор XL(73), 67-81.

Величковски, Боне (2016). Институционализацијата и предизвиците со кои се соочува Институтот за фолклор во ерата на глобализацијата. Македонски фолклор XXXVIII(71), 19-31.

Величковски, Боне (2018). Меѓу традиција и модерност - фолклорот и фолклористиката во Република Македонија. Македонски фолклор XL (73), 13-23.

Јакимовска, Илина (2018) Употребата на фолклорот во современата политичка реторика и во популарниот дискурс во Македонија. Македонски фолклор XL (73), 43-53.

Мартиноска, Ана (2018). Традиција и современост - неколку теориски перспективи во народната култура. Македонски фолклор (XL) 73, 23-33.

Bendix, Regina (1998). Of Names, Professional Identities, and Disciplinary Futures. Journal of American Folklore 111(441), 235-246.

Dundes, Alan (2005). Folkloristics in the Twenty-First Century (AFS Invited Presidential Plenary Address, 2004). Journal of American Folklore 118(470), 385-408. 


\title{
Macedonian Folklore in the $21^{\text {st }}$ Century \\ Ermis Lafazanovski
}

\section{Summary}

For the last twenty years, folklore research seems to be living on its own inertia, originating from the $20^{\text {th }}$ century, and moving along the narrow path between the crisis of its own identity and new opportunities caused by radical lifestyle changes since the beginning of the $21^{\text {th }}$ century, due to which folklore research changes its own scientific structure, theory and subject of research. Macedonian folklore is experiencing the same "turmoil", so in this context the main question that arises is which turn to take at the next crossroads.

Keywords: folkloristics, identity, methodology, theory, Macedonian folkloristics

\section{Македонски фолклор у 21. веку}

\author{
Ермис Лафазановски
}

\section{Сажетак}

Дебате које се воде у оквирима светске фолклористике, повезане с њеним предметом истраживања, методологијом и теоријом, не мимоилазе ни македонску фолклористику која у првим деценијама 21. века, покушавајући да иде у корак с најновијим истраживањима, у процесу настојања да „освежи“ властиту науку, и надахњује се из сродних хуманистичких дисциплина. У том смислу македонска фолклористика се труди да своју теорију и методологију представи као збир претходних богатих искустава која произлазе из истраживања у другој половини 20. века и нових тенденција.

Клучни зборови: фолклористика, идентитет, методологија, теорија, македонска фолклористика

\section{Ермис Лафазановски}

Институт за фолклор „Марко Цепенков“,

Скопље, Северна Македонија

Примљено: 28. 9. 2020.

Е-пошта: ermisl@ukim.edu.mk

Прихваћено: 26. 12. 2020. 